\title{
Elongated Styloid Process: A Morphometric Study, with Radiological Evaluation in Dry Human Skulls, with its Clinical Implications
}

APURBA PATRA, RAJAN KUMAR SINGLA, HARSIMARJIT KAUR, RIMPLE BANSAL, MANNAT SINGLA

\begin{abstract}
Introduction: Length of Styloid Process (SP) varies widely. It can be very short and hidden by vaginal process or it can be elongated to reach hyoid bone. The antiquity anatomists have been observing the incidence of elongated SP and their correlation with occurrence of Eagle's syndrome.
\end{abstract}

Aim: The present study aimed to determine the incidence of the elongated styloid process, their anterior and medial angulations and thickness in order to highlight their possible etiological importance in clinical and surgical conditions.

Materials and Methods: The study was done on both sides of 50 dry skulls without any obvious deformity. The length, angulations and maximum thickness of the styloid processes at base and tip were measured with the help of Vernier calipers and expressed as mean \pm SD. Each skull was carefully examined for the presence of elongated styloid process (length $>30 \mathrm{~mm}$ ). The skulls with elongated SP were separated and further investigated radiologically (digital X-ray) to know their morphology, radiographic pattern of calcification and to classify them accordingly.

Results: Out of the 100 sides of 50 skulls, elongated SP was observed on nine sides, amongst them five skulls $(10 \%)$ were with unilateral and two $(4 \%)$ with bilateral elongation of SP. The means of length, anterior and medial angulations and thickness at the level of base and tips of styloid process of right side were $21.90 \pm 8.603$ $\mathrm{mm}, 57.50 \pm 2.682^{\circ}, 65.48 \pm 2.426^{\circ}, 4.30 \pm 0.248 \mathrm{~mm}$ and $2.26 \pm 0.279 \mathrm{~mm}$, on the left side were $20.80 \pm 5.757$ $\mathrm{mm}, \quad 59.30 \pm 2.288^{\circ}, \quad 63.80 \pm 3.687^{\circ}, \quad 4.70 \pm 0.318 \mathrm{~mm}$, $2.49 \pm 0.301 \mathrm{~mm}$ respectively. The data was statistically compared between the right and left sides and found to be statistically insignificant ( $p>0.05$ ). Based on the radiological evaluation of elongated SPs, type I (elongated) morphology with partial pattern of calcification was found to be most common.

Conclusion: Elongated SP (length $>30 \mathrm{~mm}$ ) was seen more frequently unilaterally (10\%) as compared to bilateral (4\%). When bilateral, it was more on right side as compared to the left side. Whether normal or elongated, the length of SP was more on right side as compared to the left side and thickness at base and tip was more on left side as compared to the right side. Thus, right SP grows more in length while left grows more in thickness. An elongated SP is important not only clinically but also academically and ontogenically.

\section{INTRODUCTION}

The Styloid Process (SP) is a slender and cylindrical bony projection, arising from the base of the petrous temporal bone [1]. Its base lies just in front of the stylomastoid foramen and its tip projects in antero-inferior direction lying in between internal and external carotid arteries and in relation to the lateral pharyngeal wall and tonsillar fossa [2]. The structures attached to it include three muscles namely styloglossus, stylopharyngeus, stylohyoid and two ligaments namely stylohyoid and stylomandibular. Laterally, the SP is covered by the parotid gland [3]. Embryologically, SP originates from the cartilage of the second pharyngeal arch along with the stylohyoid ligament and the lesser cornu of hyoid bone; together, these three structures form an apparatus known as stylohyoid apparatus or stylohyoid complex [4]. The length of the SP normally ranges between 20 and $30 \mathrm{~mm}$ [5] and varies from person to person and even between the two sides of the same individual. The SP longer than $30 \mathrm{~mm}$ is said to be elongated. It may be unilateral or bilateral [6] and usually accompanied by calcified stylohyoid and stylomandibular 
ligaments. The elongation of the SP can trigger a series of clinical symptoms such as odynophagia, dysphagia, pain in cervicofacial region, tinnitus and trismus. The elongated SP along with this set of clinical symptoms is known as styalgia or "Eagle's syndrome" [7]. The incidence of Eagle's syndrome is very controversial [8]. Eagle found the incidence of elongated $\mathrm{SP}$ to be $4 \%$ in the general population, of which only $4 \%$ display symptoms [7]. The SP presents with widely varied morphology. The knowledge of the morphology of elongated SP is immensely important to the ENT surgeons, Dental surgeons, Anthropologists, Clinicians and Radiologists.

The prime objective of the present study was to know the incidence of elongated SP, their angulations, thickness, morphology and radiographic patterns of calcification in dry human skulls.

\section{MATERIALS AND METHODS}

This descriptive study was conducted on 50 dry human skulls of North Indian origin, irrespective of sex, obtained from the bone keeping room of Anatomy Department of Government Medical College Patiala, India, during January to April in 2016. The skulls of children, skulls with broken SP and skulls with any pathological conditions were excluded from the study. The present study mainly focused to estimate the incidence of elongated SP, their length, thickness and angulations to the different planes. The length and maximum thickness of the SP (both at the level of its base and tip) were measured with the help of digital Vernier calipers with the least count of $0.01 \mathrm{~mm}$ [Table/Fig-1]. The base of SP was considered as the junction of the petrous and tympanic portions of the temporal bone on its Inferior surface [9]. SP with length more than $30 \mathrm{~mm}$ was considered as an elongated SP [10]. According to the length, the skulls were divided into two groups.

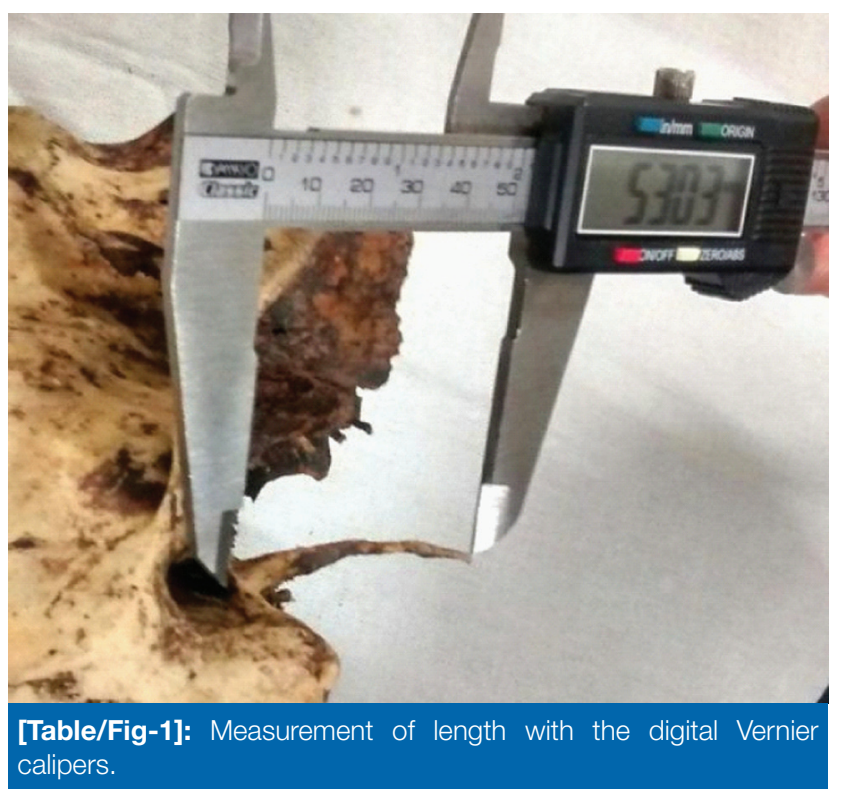

Group A: Length of SP $<30 \mathrm{~mm}$ on both the sides.

Group B: Length of SP $>30 \mathrm{~mm}$ on one or both the sides (Elongated SP). Group B was further divided into two subgroups.

Subgroup B1 with elongated SP on one side only. Subgroup B2 with elongated SP on both the sides.

Angulations were measured with the help of a protactor. The medial angle was defined as the angle on the medial side of SP between its long axis and the line connecting the bases of both SP [Table/Fig-2a] while the anterior angle was measured between Frankfurt plane and long axis of the SP on its anterior side [Table/Fig-2b]. Measurements of all the parameters studied were tabulated and compared between the normal and elongated SP.

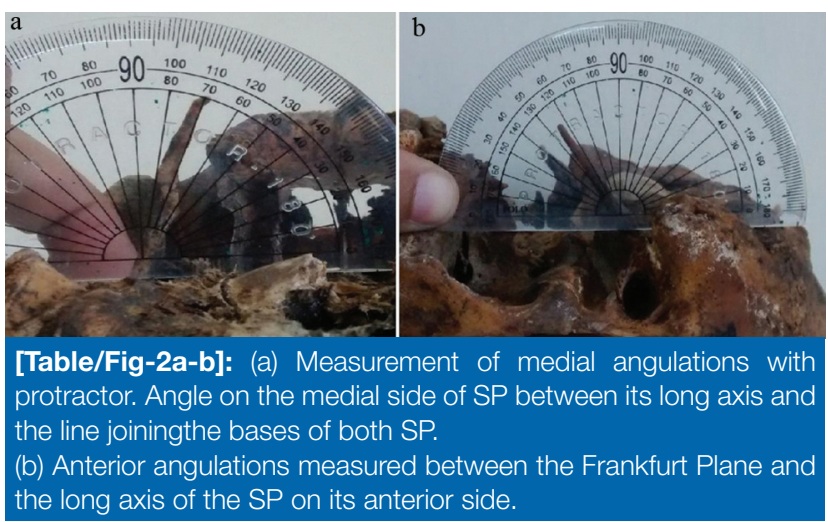

Skulls with elongated SP were further evaluated radiologically with digital X-ray to know their radiographic appearances and patterns of calcification and classified according to Langlais's classification. However, CT is useful as an adjunct for the information provided by panoramic radiographs, based on the morphology of its elongation Langlais et al., [7] proposed a new classification of elongated SP such as: Type I: Elongated SP; Type II: Pseudo articulated SP; Type III: Segmented SP and according to the pattern of calcification: (a) elongated SP with calcified outline, (b) elongated SP with partial calcification, (c) elongated SP with nodular pattern of calcification, (d) elongated SP with complete calcification.

\section{STATISTICAL ANALYSIS}

Statistical analysis of the values was done between the right and left sides of SP by using the student ' $\mathrm{t}$ ' test (paired ' $\mathrm{t}$ ' test). The significance was given as $p$-value less than 0.05 . The SPSS version 15 (SPSS Inc., Chicago, IL, USA) was used for performing the paired t test. The data were given as mean \pm standard deviation.

\section{RESULTS}

Out of the 100 sides of the 50 skulls, elongated SP (length $>30 \mathrm{~mm}$ ) was observed on nine sides. Out of which in five 
skulls, elongation was unilateral ( $R: L=3: 2)$ [Table/Fig-3a] and in two skulls, it was bilateral [Table/Fig-3b]. According to the length 43 skulls were found to be of group $A(86 \%)$ and seven skulls of group B (14\%). Out of the seven skulls of group B, five were with unilateral (subgroup B1) and two with bilateral (subgroup B2) elongation of SP.

The morphometric data of the SP obtained in the present study is represented in [Table/Fig-4] which depicts the mean

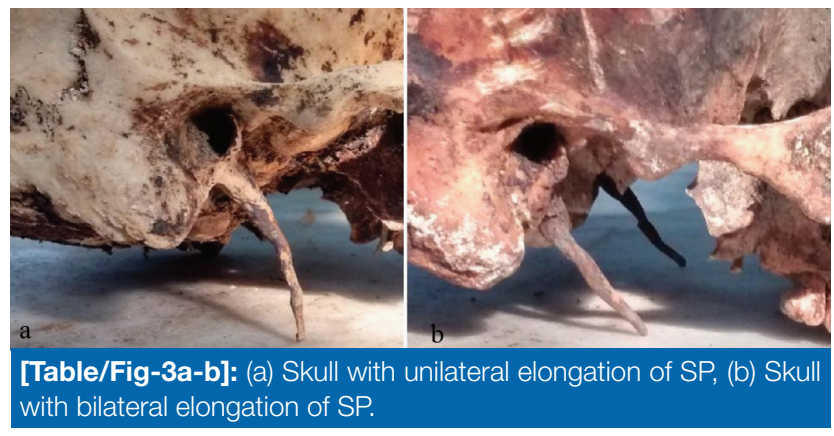

value and ranges of length, anterior and medial angulations and thickness at base and tip of the SP in the two groups as obtained in the present study. The data was statistically compared between the two sides of the skulls and difference found to be insignificant ( $p>0.05)$.

[Table/Fig-5] depicts the values of different parameters of all the skulls of Group B. It also classifies them depending upon the radiological appearance and pattern of calcification of SP. Based on the morphological characteristics of radiological appearance, out of nine elongated SPs our study found seven of type I [Table/Fig-6a], one each of type II [Table/Fig-6b] and type III [Table/Fig-6c]. According to pattern of calcification of elongated SPs, we found six with partial calcification [Table/ Fig-7a], two with nodular complex pattern [Table/Fig-7b] and one with complete calcification [Table/Fig-7c].

\section{DISCUSSION}

1) Incidence of Elongated SP: As observed in the present study out of 50 skulls, the elongated SP was seen unilaterally

\begin{tabular}{|c|c|c|c|c|c|c|c|c|}
\hline \multirow{3}{*}{ Parameter } & \multirow{2}{*}{\multicolumn{3}{|c|}{$\begin{array}{c}\text { Group A } \\
\text { Length of SP }(<30 \mathrm{~mm}) \\
(n=43) 86 \%\end{array}$}} & \multicolumn{4}{|c|}{$\begin{array}{c}\text { Group B } \\
\text { Length of SP }(>30 \mathrm{~mm}) \\
(n=7) 14 \%\end{array}$} & \multirow{3}{*}{$\begin{array}{l}\text { Total } \\
(\text { Mean) } \\
(n=50)\end{array}$} \\
\hline & & & & \multicolumn{2}{|c|}{ B1 $(n=5)$} & \multicolumn{2}{|c|}{ B2 $(n=2)$} & \\
\hline & Side & Mean & Range & Mean & Range & Mean & Range & \\
\hline \multirow{2}{*}{ Length (mm) } & $\mathrm{R}$ & 19.52 & $13-24$ & 44 & $39-53$ & 44 & $43-45$ & $21.90 \pm 8.603$ \\
\hline & L & 19.32 & $12-23$ & 36 & $35-37$ & 39.5 & $38-41$ & $20.80 \pm 5.757$ \\
\hline \multirow{2}{*}{$\begin{array}{l}\text { Anterior angle } \\
\text { (degree) }\end{array}$} & $\mathrm{R}$ & 57.50 & $56-63$ & 58 & $47-67$ & 57 & $53-61$ & $57.50 \pm 2.682$ \\
\hline & $\mathrm{L}$ & 59.40 & $54-61$ & 59 & $55-63$ & 56.5 & $54-59$ & $59.30 \pm 2.288$ \\
\hline \multirow{2}{*}{$\begin{array}{l}\text { Medial angle } \\
\text { (degree) }\end{array}$} & $\mathrm{R}$ & 65.50 & 63-79 & 67.6 & $65-70$ & 62 & $61-63$ & $65.48 \pm 2.426$ \\
\hline & $\mathrm{L}$ & 62.50 & $60-72$ & 69 & $63-75$ & 57.5 & $55-60$ & $63.80 \pm 3.687$ \\
\hline \multirow{2}{*}{$\begin{array}{l}\text { Thickness at base } \\
(\mathrm{mm})\end{array}$} & $\mathrm{R}$ & 4.37 & $4.1-5.1$ & 3.8 & $3.5-4.0$ & 3.55 & $3.5-3.6$ & $4.3 \pm 0.248$ \\
\hline & $L$ & 4.73 & $4.3-5.3$ & 4.45 & $4.3-4.6$ & 4.05 & $4.0-4.1$ & $4.7 \pm 0.318$ \\
\hline \multirow{2}{*}{$\begin{array}{l}\text { Thickness at the } \\
\text { Tip (mm) }\end{array}$} & $\mathrm{R}$ & 2.33 & 2.1-3.5 & 2.03 & $1.8-2.3$ & 1.95 & $1.8-2.1$ & $2.26 \pm 0.279$ \\
\hline & L & 2.51 & $2.3-3.8$ & 2.45 & $2.4-2.5$ & 2.1 & $2.0-2.2$ & $2.49 \pm 0.301$ \\
\hline
\end{tabular}

[Table/Fig-4]: Showing morphometric values of different parameters of the SP under study.

\begin{tabular}{|c|c|c|c|c|c|c|c|c|c|}
\hline \multirow{3}{*}{$\begin{array}{c}\text { Sample } \\
\text { No }\end{array}$} & \multirow{3}{*}{ Side } & \multirow{3}{*}{$\begin{array}{l}\text { Length } \\
\text { (in } \mathrm{mm} \text { ) }\end{array}$} & \multirow{3}{*}{$\begin{array}{l}\text { Anterior } \\
\text { Angle } \\
\text { (in degree) }\end{array}$} & \multirow{3}{*}{$\begin{array}{c}\text { Medial } \\
\text { Angle } \\
\text { (in degree) }\end{array}$} & \multicolumn{2}{|c|}{ Thickness (mm) } & \multicolumn{3}{|c|}{ Radiographic Appearance } \\
\hline & & & & & \multirow{2}{*}{$\begin{array}{c}\text { At } \\
\text { Base }\end{array}$} & \multirow{2}{*}{$\begin{array}{l}\text { At } \\
\text { Tip }\end{array}$} & \multicolumn{2}{|c|}{ Morphological Characteristics } & \multirow{2}{*}{$\begin{array}{c}\text { Patterns of } \\
\text { Calcifications }\end{array}$} \\
\hline & & & & & & & Types & Nomenclature & \\
\hline $1 a$ & Right & 43 & 53 & 63 & 3.6 & 1.8 & 1 & Elongated & Partial \\
\hline $1 b$ & Left & 38 & 54 & 55 & 4.0 & 2.2 & I & Elongated & Complete \\
\hline $2 \mathrm{a}$ & Right & 45 & 61 & 61 & 3.5 & 2.1 & III & Segmented & Nodular Complex \\
\hline $2 \mathrm{~b}$ & Left & 41 & 59 & 60 & 4.1 & 2.0 & I & Elongated & Partial \\
\hline 3 & Right & 53 & 67 & 70 & 3.5 & 1.8 & I & Elongated & Partial \\
\hline 4 & Right & 40 & 47 & 65 & 3.9 & 2.3 & $\|$ & Segmented & Nodular Complex \\
\hline 5 & Right & 39 & 60 & 68 & 4.0 & 2.0 & I & Elongated & Partial \\
\hline 6 & Left & 37 & 55 & 75 & 4.3 & 2.4 & I & Elongated & Partial \\
\hline 7 & Left & 35 & 63 & 63 & 4.6 & 2.5 & I & Elongated & Partial \\
\hline
\end{tabular}

[Table/Fig-5]: Showing length, angulations and thickness of elongated SP. 

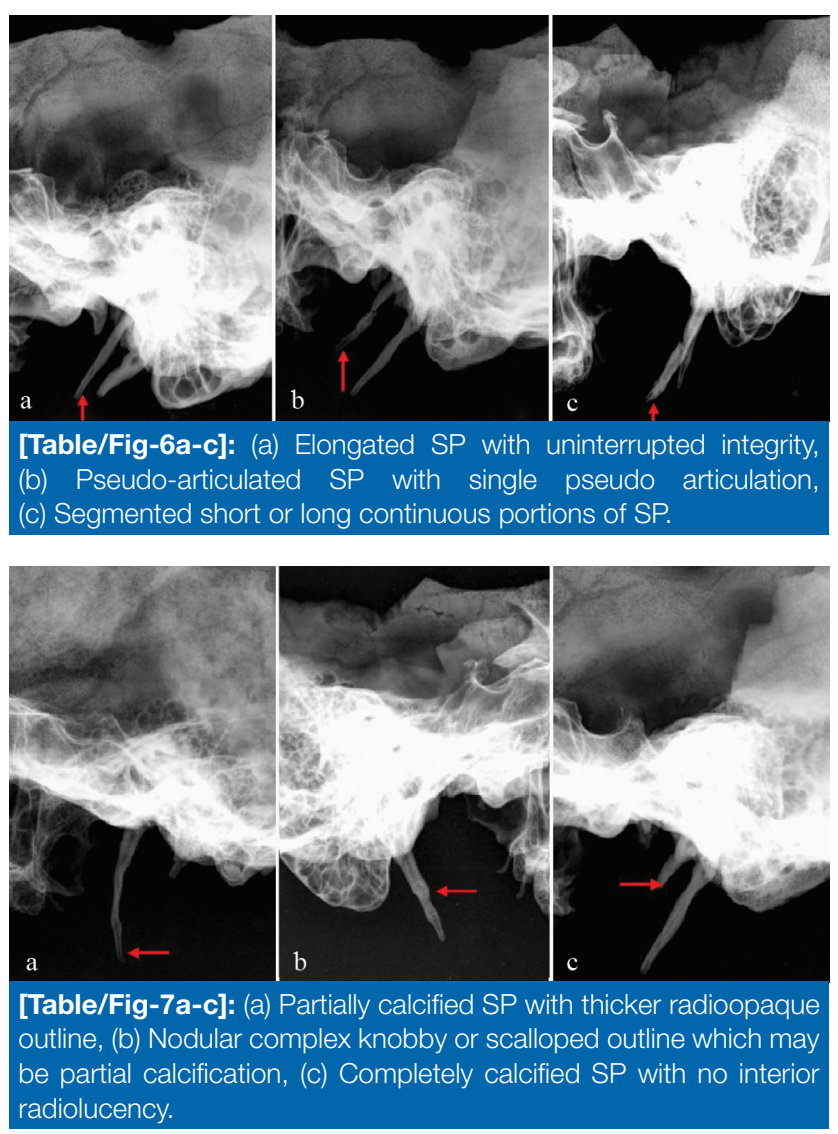

in five skulls (10\%) and bilaterally in two skulls (4\%). [Table/ Fig-8] compares the incidence of elongated SP with the earlier studies.

\begin{tabular}{|l|l|c|}
\hline \multicolumn{1}{|c|}{ Author (year) } & \multicolumn{1}{|c|}{$\begin{array}{c}\text { Population } \\
\text { Under Study }\end{array}$} & $\begin{array}{c}\text { Incidence } \\
\text { (\%) }\end{array}$ \\
\hline Eagle et al., [1] (1958) & - & 4.0 \\
\hline Keur et al., [11] (1986) & - & 30 \\
\hline Rath et al., [12] (1991) & Indian & 0.40 \\
\hline Gozil et al., [13] (2001) & - & 13.3 \\
\hline Ilguy et al., [14] (2005) & Turkish & 3.7 \\
\hline Kursoglu et al., [15] (2005) & Turkish & 83.6 \\
\hline Sisman et al., [16] (2009) & - & 7.7 \\
\hline Bagga et al., [17] (2012) & Indian & 52.1 \\
\hline Natsis et al., [18] (2014) & Greek & 26.7 \\
\hline Patil et al., [19] (2014) & Indian & 14 \\
\hline Vadgaonkar et al., [20] (2015) & Indian & 4.5 \\
\hline Vieira et al., [21] (2015) & Central brazilian & 43.89 \\
\hline Present study (2016) & Indian & 9 \\
\hline [Table/Fig-8]: Showing comparison of incidence of elongated SP.
\end{tabular}

As evident from [Table/Fig-8] incidence of elongated SP varies between $0.40 \%$ to $83.6 \%$ in dry skull. However, all of the earlier authors are silent about the unilateral or bilateral elongation of $\mathrm{SP}$, the same is being reported here. The elongation is seen more frequently unilaterally $(10 \%)$ as compared to bilaterally (4\%). As far as side preponderance is concerned, it is seen more frequently on the right side (three out of five unilateral elongations) as compared to the left (two out of five elongations). Thus it is in consonance with earlier studies done by Natsis et al., [18] who reported it to be more frequent on the right side than the left in Greek population whereas it is contrary with the findings of Vadgaonkar et al., [20] who studied dried skulls of South Indian origin and found it to be more on the left side.

2) Length of SP: As evident from [Table/Fig-4], the mean length of SP was more on the right side as compared to the left in all the groups (group A, B1 and B2). While the difference was just $0.2 \mathrm{~mm}$ in group $\mathrm{A}$, it was much more in group B1

\begin{tabular}{|l|l|c|}
\hline \multicolumn{1}{|c|}{ Author (year) } & \multicolumn{1}{|c|}{$\begin{array}{c}\text { Population } \\
\text { Under Study }\end{array}$} & $\begin{array}{c}\text { Mean Length } \\
\text { (mm) }\end{array}$ \\
\hline Gozil et al., [13] (2001) & Turkish & 28.42 \\
\hline Patil et al., [19] (2015) & Indian & 23.8 \\
\hline Monsour et al., [22] (1986) & - & 29.20 \\
\hline Camarda et al., [23] (1989) & Canadian & 10 \\
\hline Basekim et al., [24] (2005) & Turkish & 28.30 \\
\hline Balcioglu et al., [25] (2009) & Turkish & 22.54 \\
\hline Shaik et al., [26] (2013) & Saudi Arabian & 36.7 \\
\hline Present study (2016) & Indian & $21.90(\mathrm{R}), 20.80(\mathrm{~L})$ \\
\hline
\end{tabular}

[Table/Fig-9]: Showing comparison of the mean of length of SP.

$(8 \mathrm{~mm})$ and group B2 $(4.5 \mathrm{~mm})$. This indicates that when the SP is of normal length the difference on two sides is not marked but when it is elongated the length increases much more on the right side than the left. For the same reasons incidence of elongated SP is more on the right side. The present study reported the presence of side asymmetry in the elongated SP. The same was also found by Rath and Anand [12], according to them this side asymmetry with more incidence of right sided elongated SP might be due to the fact that right side of the jaw was more active during mastication specially in right handed person. [Table/Fig-9] compares the mean length of SP as observed by earlier workers with our findings. In all of these the length varies between 22-29 mm except in a study by Camarda et al., [23] and Shaik et al., [26] who found it to be $10 \mathrm{~mm}$ and $36.7 \mathrm{~mm}$ respectively. This difference may be attributed to the racial factors.

Clinical implications: Although, elongation of SP is not an uncommon phenomenon, it causes symptoms rarely. It may cause various problems giving rise to a clinical syndrome popularly known as Eagle's syndrome. It may also compress the surrounding anatomical structures in the neck region like carotid artery, sympathetic plexus around the artery, vagus nerve and cause difficulty in deglutition, foreign body sensation in the neck, pain during rotation of neck, and carotid pain. 
In extreme condition compression over sympathetic plexus can give rise to myocardial infarction. There are few other clinical conditions like cervical osteophytes, spondylosis, and anomalies of vertebral arterial system which may be associated with elongated SP as an incidental finding. Elongation due to ossification of stylohyoid ligament makes it very fragile and if present may get fractured following trivial trauma.

3) Angulations of SP: As evident from [Table/Fig-4] the mean of anterior angulations of SP was more on the left as compared to the right in group $\mathrm{A}$ and $\mathrm{B} 1$, while the reverse was true in group B2.

However, the difference was statistically insignificant in all the groups. The mean of medial angulations of SP was more on the right than on the left in group A and B2 whereas in group B1 it was more on the left side. These differences were also statistically insignificant. [Table/Fig-10] compares the mean values of anterior and medial angulations as observed by the earlier authors with the present study. While our results are almost in consonance with Patil et al., [19], there seems to be a great difference with others viz. Yavuz et al., [27] and Mazzetto et al., [28]. It is because of the fact that, these authors have measured the angles with respect to the vertical plane while in the present study these were measured with respect to the horizontal plane. If we deduce these angles with respect to the horizontal plane then these turn out to be $70.10^{\circ}, 69.11^{\circ}$ as anterior angulations and $73.60^{\circ}, 70.90^{\circ}$ as medial angulations which are almost in consonance with our study.

\begin{tabular}{|l|l|c|c|}
\hline Author (year) & Population & $\begin{array}{c}\text { Mean of Anterior } \\
\text { Angulations } \\
\text { (degree) }\end{array}$ & $\begin{array}{c}\text { Mean of Medial } \\
\text { Angulations } \\
\text { (degree) }\end{array}$ \\
\hline $\begin{array}{l}\text { Patil et al., [19] } \\
\text { (2014) }\end{array}$ & Indian & 62.45 & 74.15 \\
\hline $\begin{array}{l}\text { Yavuz et al., } \\
\text { [27] (2008) }\end{array}$ & Turkish & 19.90 & 16.40 \\
\hline $\begin{array}{l}\text { Mazzeto et al., } \\
\text { [28] (2013) }\end{array}$ & Brazilian & 20.89 & $19.1(\mathrm{R}), 19.04(\mathrm{~L})$ \\
\hline $\begin{array}{l}\text { Present study } \\
\text { (2016) }\end{array}$ & Indian & $57.50(\mathrm{R}), 59.30(\mathrm{~L})$ & $65.48(\mathrm{R}), 63.80(\mathrm{~L})$ \\
\hline
\end{tabular}

[Table/Fig-10]: Showing comparison of the means of angulations.

Clinical implications: Ilguy et al., [14] described a variety of factors that cause symptoms of styalgia or Eagle's syndrome, including the length, width, angulations, direction of deviation and the degree of calcification of the SP. The direction and angulations of the elongated SP have been held responsible by Strauss et al., [29] for irritating the nerves and vessels passing through the parapharyngeal space. Length of SP being in normal range, its medial deviation can cause impingement of the structures in the tonsillar fossa [30], while anterior deviation may irritate the mucosa and cause pressure damage over vital structures lying in the same area [27]. An elongated
SP with slight deviation from its normal direction can cause impingement of the internal or external carotid artery within the carotid sheath leading into its painful palpation as it stimulates the sympathetic plexus accompanying the artery [31].

4) Thickness of SP: As evident from [Table/Fig-4], the thickness of SP both at the base and tip was more on the left side than on the right in all the groups (group A, B1, B2). This may be due to the fact that the mean of length of SP was more on the right side than on the left in all the groups. Thus these observations can lead us to conclude that right SP grows more in length while left SP grows more in thickness in both the groups i.e., normal and elongated SP. The mean thickness at the base of the SP was $4.3 \pm 0.248 \mathrm{~mm}$ and $4.7 \pm 0.318 \mathrm{~mm}$ on the right and left sides, respectively. Whereas, at the tip the same parameter was $2.26 \pm 0.279 \mathrm{~mm}$ and $2.46 \pm 0.301$ $\mathrm{mm}$ on the right and left sides, respectively. The difference of thickness between the two sides was statistically insignificant both at the level of the base and tip. As there is scarcity of literatures discussing thickness of SP, the findings of our study could only be compared with the findings of Vadgaonkar et al., [20], who reported base thickness to be $4.4 \mathrm{~mm}$ which is almost in consonance with our findings.

Clinical implications: An unusual increase in thickness at the base of SP can cause facial nerve compression while coming out of stylomastoid foramen. However, thickness of the tip is clinically more important as it is related to the neurovascular bundle. As SP increases in length, its tip becomes sharper and may cause injury to the neurovascular bundle.

5) Radiographic classification of elongated SP: There are many variations in the radiographic pattern of elongated styloid chain including the uninterrupted integrity of mineralised SP, presence of pseudo-articulation, presence of short and long segments of mineralised ligament and patterns of calcification. Therefore, to describe the radiographic appearance of elongated SP it is necessary to define its morphological type of elongation and pattern of calcification. Langlaiset al., [7] proposed a simple and useful radiographic classification of elongated SP based on the type of elongation and patterns of calcification [Table/Fig-11,12]. We have followed the similar classification in the present study to describe the morphology and patterns of calcification of the SP. The digital panoramic radiographs rather than computed tomography were used to find types and patterns of calcification of elongated SP. Type I morphology with partial calcification was found to be the most common radiographic pattern in the present study. Similar findings were noticed by llgüyet al., [14] and Bagga et al., [17]. Reddy et al., [32] reported type I as most common morphological type of elongated SP while completely calcified pattern as the most prevalent in south Indian population.

Clinical implications: Panoramic radiographs help not only to define the type of elongated SP but also classify them according to pattern of calcification. Elongated SP 


\begin{tabular}{|c|l|l|}
\hline Types & Nomenclature & \multicolumn{1}{c|}{ Radiographic Appearances } \\
\hline I & Elongated & $\begin{array}{l}\text { Uninterrupted integrity of styloid image } \\
(>25-28 \mathrm{~mm})\end{array}$ \\
\hline II & $\begin{array}{l}\text { Pseudo- } \\
\text { articulated }\end{array}$ & $\begin{array}{l}\text { Styloid process is joined to the } \\
\text { mineralised stylomandibular or } \\
\text { stylohyoid ligament by a single pseudo } \\
\text { articulation, usually located superior to } \\
\text { inferior border of the mandible. }\end{array}$ \\
\hline III & Segmented & $\begin{array}{l}\text { Short or long continuous portions of } \\
\text { the styloid process or uninterrupted } \\
\text { segments of mineralised ligament }\end{array}$ \\
\hline
\end{tabular}

[Table/Fig-11]: Different types of elongated SP depending upon morphological characteristics.

\begin{tabular}{|l|l|}
\hline \multicolumn{1}{|c|}{ Patterns } & \multicolumn{1}{c|}{ Radiographic Appearances } \\
\hline Calcified Outline & $\begin{array}{l}\text { Thin radiopaque cortex and a central } \\
\text { lucency that constitutes most of the process }\end{array}$ \\
\hline Partially Calcified & $\begin{array}{l}\text { Thicker radioopaque outline with almost } \\
\text { complete opacification as well as small and } \\
\text { occasionally discontinuous radiolucent core. }\end{array}$ \\
\hline Nodular Complex & $\begin{array}{l}\text { Knobby or scalloped outline which may } \\
\text { be partially calcified with varying degree of } \\
\text { central radiolucency. }\end{array}$ \\
\hline $\begin{array}{l}\text { Completely } \\
\text { Calcified }\end{array}$ & $\begin{array}{l}\text { Totally radiopaque with no evidence of } \\
\text { radiolucent interior }\end{array}$ \\
\hline
\end{tabular}

[Table/Fig-12]: Different patterns of elongated SP depending upon its calcification.

may remain asymptomatic or may present with features of compression symptoms to the surrounding structures. If any of the symptoms exist, digital palpation of the SP is a simple diagnostic procedure during the routine examination. SP with normal length is not usually palpable, so the digital palpation may easily reveal the problem. In addition to the physical examination, use of non-invasive imaging method such as Panoramic radiographs is gold standard to confirm the final diagnosis and plan intervention accordingly. .

Ontogeny: Embryologically an independent cartilage anlage near the dorsal end of second pharyngeal arch cartilage, also closely related to the developing ear, ossifies to form the SP of the temporal bone. The part of the cartilage between the SP and hyoid bone regresses; its perichondrium forms the stylohyoid ligament and the ventral end of the second arch cartilage ossifies to form the lesser cornu of the hyoid [33].Occasionally ossification of the second arch cartilage may extend from the SP along the stylohyoid ligament. However, various authors have made an effort to explain its aetiopathogenesis but it remains questionable. According to Steinmann [34], calcified stylohyoid ligament is a developmental malformation. Embryologically the stylohyoid chain is composed of four distinct segments namely, tympanohyal, stylohyal, ceratohyal and hypohyal. These four segments ossify separately in parts. The SP which develops from tympanohyal and stylohyal segments usually fuse at the age of puberty. The hypohyal segment gives rise to the lesser cornu. The stylohyoid ligament which connects SP with lesser cornu originates from the ceratohyal segment [4]. Although various authors have proposed different theories regarding causation of SP elongation, the actual cause still remains unknown. Murtagh et al., [35] proposed various theories of elongation, such as:

1. Congenital elongation due to persistence of a cartilaginous anlage.

2. Calcification of the stylohyoid ligament by an unknown cause.

3. Growth of osseous tissue at the insertion of the stylohyoid ligament.

Accordingly findings in our study fit into the theory of calcification of the stylohyoid ligament due to unknown cause.

\section{LIMITATION}

Sample size was comparatively small in our study and also we didn't consider sex of the sample as our study was done on dry human skulls.

\section{CONCLUSION}

Elongated SP (length>30 mm) was seen more frequently unilaterally (10\%) as compared to bilateral (4\%). When bilateral, it was more on right side as compared to the left side. Whether normal or elongated, the length of SP was more on right side as compared to the left side and thickness at base and tip was more on left side as compared to the right side. Thus, right SP grows more in length while left grows more in thickness. An elongated SP is important not only clinically but also academically and ontogenically.

\section{REFERENCES}

[1] Eagle WW. The symptoms diagnosis and treatment of elongated styloid process. Am surg. 1962;28:01-05.

[2] Standring S. Skull and Mandible. In Gray's Anatomy. The Anatomical basis of clinical practice. $39^{\text {th }}$ ed. Edinburg: Elsevier; 2005. p470.

[3] Williams PL. Gray's Anatomy. 38 th Ed. London: ELBS with Churchill Livingstone; 1999.

[4] Rodriguez Vazquez JF, Merida Velasco JR, Verdugo Lopez S, Sanchez Montesinos I, Merida Velasco JA. Morphogenesis of the second pharyngeal arch cartilage (Reichert's cartilage) in human embryos. J Anat. 2006;208(2):179-89.

[5] Sokler K, Sandev S. New classification of the styloid process length-clinical application on the biological base. Coll Anthropol. 2001;25:627-32.

[6] Gokce C, Sisman Y, Tarim E, Akgunlu F, Ozturk A. Prevalence of styloid process elongation on panoramic radiography in the Turkey population from Cappodocia region. Eur $J$ Dent. 2008;2:18-22.

[7] Langlais RP, Miles DA, Van Dis ML. Elongated and mineralized stylohyoid ligament complex: A proposed classification and report of a case of Eagle's syndrome. Oral Surg Oral Med Oral Pathol. 1986;61:527-32.

[8] Rogers K, Chang H. Eagle's syndrome: A case report. Columbia Dent Rev. 2007;11:12-14. 
[9] Cawich S, Gardner M, Shetty R, Harding H. A post mortem study of elongated styloid processes in a Jamaican population. The Internet J Biological Anthropol. 2008; 3:01-06.

[10] Palesy P, Murray GM, De Boever J, Klineberg I. The involvement of the styloid process in head and neck pain-A preliminary study. J Oral Rehabil. 2000; 27:275-87.

[11] Keur JJ, Campbell JP, McCarthy JF, Ralph WJ. The clinical significance of the elongated styloid process. Oral Surg Oral Med Oral Pathol. 986;61:399-404.

[12] Rath G, Anand C. Abnormal styloid process in a human skull. Surg Radiol Anat. 1991;13:227-29.

[13] Gozil R, Yener N, Calguner E. Morphological characteristics of styloid process evaluated by computerized axial tomography. Ann Anat. 2001;183:527-35.

[14] Ilguy M, Ilguy D, Guler N, Bayirli G. Incidence of the type and calcification patterns in patients with elongated styloid process. J Int Med Res. 2005;33:96-102.

[15] Kursoglu P, Unalan F, Erdem T. Radiological evaluation of the styloid process in young adults resident in Turkey's Yeditepe University faculty of dentistry. Oral Surg Oral Med Oral Pathol Oral Radiol Endod. 2005;100:491-94.

[16] Sisman Y, Gokce C, Tarim E. Investigation of elongated styloid process prevalence in patients with torus palatines. Clin Oral Investig. 2009;13:269-72.

[17] Bagga MB, Kumar CA, Yeluri G. Clinicoradiologic evaluation of styloid process calcification. Imaging Sci Dent. 2012;42:15561.

[18] Natsis K, Repousi E, Noussios G, Papathanasiou E, Apostolidis S, Piagkou M. The styloid process in a Greek population: an anatomical study with clinical implications. Anat Sci Int. 2015;90(2):67-74.

[19] Patil S, Ghosh S, Vasudeva N. Morphometric study of the styloid process of temporal bone. J Clin Diagn Res. 2014;8(9):04-06.

[20] Vadgaonkar R, Murlimanju BV, Latha V. Prabhu, Rai R, Pai MM, Tonse M, et al. Morphological study of styloid process of the temporal bone and its clinical implications. Anat Cell Biol. 2015;48:195-200.

[21] Vieira EM, Guedes OA, De Morais S, De Musis CR, De Albuquerque PA, Borges ÁH. Prevalence of Elongated styloid process in a Central Brazilian Population. J Clin Diagn Res. 2015:9:ZC90-92.
[22] Monsour P, Young W. Variability of the styloid process and stylohyoid ligament in panoramic radiographs. Oral Surg Oral Med Oral Pathol. 1986;61:522.

[23] Camarda AJ, Deschamps C, Forest DI. Stylohyoid chain ossification: a discussion of etiology. Oral Surg Oral Med Oral Pathol. 1989;67:508-14.

[24] Basekim CC, Mutlu H, Güngör A, Silit E, Pekkafali Z, Kutlay M et al. Evaluation of styloid process by three-dimensional computed tomography. Eur Radiol. 2005;15:134-39.

[25] Balcioglu HA, Kilic C, Akyol M, Ozan H, Kokten G. Length of the styloid process and anatomical implications for Eagle's syndrome. Folia Morphol (Warsz). 2009;68:265-70.

[26] Shaik MA, Naheeda, Kaleem SM, Wahab A, Hameed S. Prevalence of elongated styloid process in Saudi population of Aseer region. Eur J Dent. 2013;7(4):449-54.

[27] Yavuz H, Caylakli F, Yildirim T, Ozluoglu LN. Angulation of the styloid process in Eagle's syndrome. Eur Arch Otorhinolaryngol. 2008;265:1393-96.

[28] Mazzetto MO, Andrade KM, Magri LV, Rodrigues CA, Watanabe PC. Anterior and medial angulations of the styloid process in subjects with TMD: clinical and radiographic findings. Braz Dent J. 2013;24:80-84.

[29] Strauss M, Zohar $Y$, Laurian N. Elongated styloid process syndrome: intraoral versus external approach for styloid surgery. Laryngoscope. 1985;95(8):976-79.

[30] Ghosh LM, Dubey SP. The syndrome of elongated styloid process. AurisNasus Larynx. 1999;26(2):169-75.

[31] Chuang WC, Short JH, McKinney AM, Anker L, Knoll B, McKinney ZJ. Reversible left hemispheric ischemia secondary to carotid compression in Eagle syndrome: surgical and CT angiographic correlation. Am J Neuro radiol. 2007;28:143-45.

[32] Reddy RS, Kiran CH, Madhavi NS, Raghavendra MN, Satish A. Prevalence of elongation and calcification patterns of elongated styloid process in South India. J Clin Exp Dent. 2013;5:30-35.

[33] Moore KL, Persaud TVN. The developing human clinically oriented embryology. $8^{\text {th }}$ ed. Philadelphia:Saunders; 2008.

[34] Steinmann EP. Styloid syndrome in absence of an elongated process. Acta Otolaryngol. 1968;66:347-56.

[35] Murtagh RD, Carcciolo JT, Fernandez G. CT findings associated with Eagle's syndrome. Am J Neuraradiol. 2001;22:1401-02.

\section{AUTHOR(S):}

1. Dr. Apurba Patra

2. Dr. Rajan Kumar Singla

3. Dr. Harsimarjit Kaur

4. Dr. Rimple Bansal

5. Ms. Mannat Singla

\section{PARTICULARS OF CONTRIBUTORS:}

1. Senior Resident, Department of Anatomy, Government Medical College Patiala, Punjab, India.

2. Professor, Department of Anatomy, Government Medical College Patiala, Punjab, India.

3. Associate Professor, Department of Anatomy, Government Medical College Patiala, Punjab, India.
4. Senior Resident, Department of Anatomy, Government Medical College Patiala, Punjab, India.

5. Student, Department of Anatomy, Government Medical College Patiala, Punjab, India.

\section{NAME, ADDRESS, E-MAIL ID OF THE CORRESPONDING AUTHOR:}

Dr. Apurba Patra,

House No. 15E, Rajindra Medical Complex, New Lal Bagh Colony Patiala, Punjab-147001, India.

E-mail: apurba.cnmc03@gmail.com

FINANCIAL OR OTHER COMPETING INTERESTS: None. 